\title{
KORELASI ANTARA HASIL DAN KOMPONEN HASIL BEBERAPA KULTIVAR PADI GOGO (Oryza sativa L.) LOKAL SULAWESI TENGGARA PADA DUA SISTEM BUDIDAYA
}

\section{Yield and Yield Components Correlation of Some Local Upland Rice Cultivars (Oryza sativa L.) in Upland and Wetland Cultivation Systems}

\author{
Laode Afa ${ }^{1)^{*}}$, Suaib ${ }^{1)}$, Ilan Uge ${ }^{2)}$, Arsy Aysyah Anas ${ }^{1)}$ dan Maisura ${ }^{3)}$ \\ ${ }^{1}$ Dosen Jurusan Agroteknologi Fakultas Pertanian Universitas Halu Oleo \\ ${ }^{2}$ Mahasiswa S1 Jurusan Agroteknologi Fakultas Pertanian Universitas Halu Oleo \\ J1. H.E.A Mokodompit Kampus Hijau Bumi Tridharma Anduonohu Kendari, Southeast \\ Sulawesi 93232, Indonesia. \\ ${ }^{3}$ Dosen Jurusan Agroekoteknologi Fakultas Pertanian Universitas Malikussaleh \\ *) Corresponding author: laodeafaafa@yahoo.com
}

\begin{abstract}
ABSTRACK
The purpose of this research was to study the correlation between yield and its components of local upland rice cultivars of Southeast Sulawesi that have been cultivated in upland or wetland rice systems. The research has been conducted on experimental fields located in Kambu Village, Kambu District, Kendari Municipality, and in the Agrotechnology Laboratory, Faculty of Agriculture Halu Oleo University. This study was conducted from Mei to October 2017, and the design of a single factor treatment was arranged in a randomized block design. Both cultivation systems were dryland and wetland, while the cultivar factor consisted of 6 level varieties i.e: Wapantoga, Bou, Momea, Konkep, Uwa, and Ndowatu. Each variety in each cultivated system was classified into 3 groups as replication so that there were 36 experimental units. The results of the research showed that the length of the panicle, total grains per panicle, 1000 grain weight, and grain weight per boots were the variables that have a positive correlation to the yield production of both cultivation systems. These yield components have a positive correlation of rice yield against local upland rice cultivars.
\end{abstract}

Keywords; Correlation, dryland, local upland rice, wetland.

\begin{abstract}
ABSTRAK
Tujuan dari penelitian ini yaitu untuk mempelajari keeratan hubungan hasil dan komponen-komponen hasil padi ladang lokal Sulawesi Tenggara yang dibudidayakan dengan sistem budidaya gogo dan budidaya sawah. Penelitian telah dilaksanakan pada lahan yang terletak di Kelurahan Kambu Kota Kendari dan di Laboratorium Agroteknologi Fakultas Pertanian Universitas Halu Oleo. Penelitian ini berlangsung dari bulan Mei sampai Oktober 2017. Rancangan percobaan yang digunakan adalah Rancangan Acak Kelompok Lengkap (RAKL) yang terdiri atas 6 perlakuan kultivar yaitu Wapantoga, Bou, Momea, Konkep, Uwa dan Ndowatu dalam dua sistem budidaya yaitu sistem budidaya gogo dan sistem budidaya sawah. Setiap perlakuan kultivar diulang 3 kali sebagai kelompok sehingga terdapat 36 unit percobaan. Hasil penelitian menunjukkan bahwa panjang malai, total gabah per malai, bobot gabah isi dan bobot gabah per rumpun merupakan kriteria yang dapat digunakan untuk meningkatkan produksi padi ladang baik yang ditanam pada kondisi lahan kering (sistem budidaya gogo) maupun lahan sawah (sistem budidaya sawah). Empat komponen tersebut memiliki korelasi positif terhadap hasil produksi padi ladang lokal Sulawesi Tenggara.
\end{abstract}

Kata Kunci; korelasi, kultivar padi lokal, ladang, sawah. 


\section{PENDAHULUAN}

Budidaya padi ladang (Oryza sativa L.) umumnya dilakukan pada lahan tadah hujan dengan sistem budidaya gogo. Pada lahan budidaya tersebut produktivitas padi ladang $\pm 1,5$ ton per ha, dengan umur panen dapat mencapai 6 bulan (Afa \& Anas, 2017). Akhirakhir ini permintaan konsumen terhadap kebutuhan beras merah semakin meningkat, untuk memenuhi kebutuhan karbohidrat terutama bagi penderita penyakit diabetes. Upaya peningkatan produktivitas dan mengatasi umur panen yang lama terus dilakukan melalui penerapan tekonlogi budidaya yang disesuaikan dengan kondisi sosial ekonomi petani.

Teknologi budidaya dimaksud antara lain adalah pengembangan metode atau sistem budidaya di lahan potensial tetapi pengelolaannya kurang intensif seperti lahan sawah tadah hujan. Di lahan sawah tadah hujan sering terjadi kekeringan atau kelebihan air akibat kondisi iklim yang tidak stabil, yang menyebabkan indeks penanaman rendah terutama pada musim kemarau. Salah satu upaya untuk mengatasi kurangnya pasokan air dan kelebihan air pada lahan sawah tadah hujan terutama pada kondisi peralihan musim hujankemarau dan pada musim kemarau, maka dibutuhkan kultivar padi lokal yang berpotensi untuk tumbuh dan berproduksi dengan baik pada kedua kondisi lingkungan tersebut. Kartina et al., (2017) melaporkan bahwa hasil gabah padi dipengaruhi oleh lokasi produksi atau kondisi lingkungan, genotip serta interaksi genotip dan lingkungan. Selain faktor genetik, faktor lingkungan juga dapat mempengaruhi hasil tanaman (Bogale \& Tesfaye, 2016; Perween et al., 2020).

Upaya ini dapat dilakukan dengan melakukan uji kultivar padi lokal yang berpeluang untuk tumbuh dan berproduksi tinggi pada kondisi lingkungan budidaya gogo dan sawah. Hal ini dapat dilakukan dengan cara mensimulasikan kondisi lingkungan tumbuh padi ladang pada lahan kering dan lahan basah. Wirnas et al., (2007) menyatakan seleksi tersebut akan memberikan respon optimal bila didukung oleh komponen pertumbuhan dan komponen hasil yang berkorelasi kuat dengan daya hasil. Selanjutnya, Limbongan (2008) \& Rachmawati et al., (2014) menyatakan seleksi akan memberikan respon yang optimal dengan menggunakan karakter seleksi yang tepat.

Disamping itu, untuk mengetahui besarnya derajat keeratan hubungan antara komponen-komponen hasil terhadap peningkatan hasil gabah maka diperlukan korelasi. Seperti yang dikemukakan Habib et al., (2005) bahwa seleksi berdasarkan daya hasil biasanya kurang memberikan hasil yang optimal jika tidak didukung oleh karakter seleksi lain berupa komponen pertumbuhan dan komponen hasil yang berkorelasi kuat dengan daya hasil. Oleh karena itu, penelitian ini dilakukan untuk mengetahui keeratan hubungan hasil dan komponen-komponen hasil padi lokal Sulawesi Tenggara yang dibudidayakan dengan sistem budidaya gogo dan sistem budidaya sawah atau gogorancah.

\section{BAHAN DAN METODE \\ Lokasi dan Waktu Penelitian}

Penelitian ini dilaksanakan pada lahan yang sesuai dengan kondisi sistem budidaya padi ladang dan sawah yang terletak di Kelurahan Kambu Kota Kendari dan di Laboratorium Agro-teknologi Fakultas Pertanian Universitas Halu Oleo. Lokasi penelitian terletak pada koordinat $04{ }^{\circ} \mathrm{LS}$ dan $122,41{ }^{\circ} \mathrm{BT}$ dengan ketinggian tempat $\pm 13,33$ $\mathrm{m}$ dpl. Suhu rata-rata tertinggi adalah $29{ }^{\circ} \mathrm{C}$ dan suhu rata-rata terendah adalah $23{ }^{\circ} \mathrm{C}$. Penelitian ini berlangsung dari bulan Mei sampai Oktober 2017. Keadaan curah hujan selama penelitian berlangsung disajikan pada Tabel 1 .

Tabel 1. Rata-rata curah hujan selama pertumbuhan padi gogo di lokasi penelitian*)

\begin{tabular}{lcc}
\hline Fase Pertumbuhan $^{\text {b) }}$ & $\mathrm{CH}(\mathrm{mm})^{\text {a) }}$ & Frekuensi hujan (hari) \\
\hline Tanam-Primordia & 234.56 & 22.0 \\
Pembungaan-Pengisian Biji & 280.46 & 16.0 \\
Pematangan Biji & 33.19 & 5.0 \\
Masak penuh & 0 & 0 \\
\hline
\end{tabular}


Keterangan: ${ }^{*}=$ ada tambahan pengairan di awal vegetative pada sistem budidaya gogo; ${ }^{\text {a)}}=$ Hasil pengukuran langsung di lokasi penelitian menggunakan alat penakar curah hujan; ${ }^{\text {b) }}=$ Fase pertumbuhan tanaman padi varietas berumur 120 hari (Yoshida, 1981).

\section{Bahan dan Alat}

Bahan yang digunakan pada penelitian ini adalah 6 kultivar padi gogo lokal Sulawesi Tenggara (Tabel 2), Pupuk Urea, pupuk KCl, pupuk SP-36, air, kantong plastik, plasik cetik, amplop, tali rafia, label sampel, dan label perlakuan. Peralatan yang digunakan adalah jaring, paranet, pacul, ajir, papan nama, meter roll, timbangan analitik, kamera, dan alat tulis, serta sejumlah peralatan pendukung lainnya.

Tabel 2. Kultivar padi gogo lokal Sulawesi Tenggara yang digunakan dalam penelitian

\begin{tabular}{clll}
\hline No. & Nama Kultivar & Asal daerah (Kabupaten) & Warna Beras \\
\hline 1. & Wapantoga & Buton Utara & Merah \\
2. & Bou & Konawe Selatan & Merah \\
3. & Momea & Konawe Selatan & Merah \\
4. & Konkep & Konawe Kepulauan & Putih \\
5. & Uwa & Konawe Selatan & Putih \\
6. & Ndowatu & Konawe Selatan & Putih \\
\hline
\end{tabular}

\section{Rancangan Penelitian}

Rancangan percobaan yang digunakan adalah Rancangan Acak Kelompok Lengkap (RAKL) yang terdiri atas 6 perlakuan kultivar yaitu Wapantoga, Bou, Momea, Konkep, Uwa dan Ndowatu dengan dua sistem budidaya yaitu sistem budidaya gogo dan sawah. Setiap perlakuan kultivar diulang 3 kali sebagai kelompok sehingga terdapat 36 unit percobaan.

\section{Prosedur Penelitian}

\section{Persiapan Lahan dan Pengolahan Tanah}

Persiapan lahan dilakukan sesuai dengan sistem budidaya yang digunakan yaitu sistem budidaya gogo dan sistem budidaya sawah. Sistem budidaya gogo, pengolahan tanah dilakukan tiga kali agar diperoleh bedengan/petakan tanah yang baik, tahapan pengolahan tanah pertama (membolak-balikkan tanah), pengolahan tanah ke dua (penggemburan) serta pembuatan petakan. Sistem budidaya sawah, pengolahan tanah dilakukan dengan tahapan sebagai berikut: pengolahan tanah menggunakan pacul, penggenangan (inkubasi) selama \pm 1 minggu, kemudian dilakukan pelumpuran dan diikuti dengan perataan petakan.

Ukuran petak percobaan adalah $100 \mathrm{~cm} \times 100 \mathrm{~cm}$, dan masing-masing petak diulang 3 kali. Untuk memisahkan antar perlakuan dibuat jarak dengan lebar $30 \mathrm{~cm}$, sedangkan antar kelompok dibuat dengan lebar $60 \mathrm{~cm}$.

\section{Persiapan Benih}

Dipilih benih yang memiliki ukuran yang relatif seragam dari masing-masing kultivar, kemudian dilakukan perendaman/pemeraman selama $\pm 2 \times 24$ jam sampai muncul radikula $\pm 2 \mathrm{~mm}$. Banyaknya benih tiap kultivar yang disiapkan sebagai bahan tanam yaitu 250 biji per kultivar.

\section{Penanaman}

Benih yang telah muncul radikula \pm 2 $\mathrm{mm}$ kemudian ditanam pada petak percobaan yang sudah disiapkan. Penanaman dilakukan dengan cara ditugal/dibenamkan sedalam \pm 2 $\mathrm{cm}$. Tiap lubang tanam ditanami 2 benih dengan jarak tanam $25 \times 25 \mathrm{~cm}$. Setiap petak terdapat 16 rumpun.

\section{Pemeliharaan}

Tindakan pemeliharaan yang dilakukan meliputi: 
a. Penjarangan/Penyulaman

Penjarangan dilakukan pada umur 10 hari setelah tanam (HST). Penjarangan dilakukan dengan cara mencabut 1 tanaman dari 2 tanaman yang tumbuh tiap lubang sehingga tersisa 1 tanaman pada setiap lubang tanam. Penyulaman dilakukan untuk mengganti tanaman yang tidak tumbuh, menggunakan tanaman dari tanaman sulaman yang ditanam secara khusus pada masing-masing kultivar.

b. Pengairan

Pengairan atau pemberian air disesuaikan dengan perlakuan sistem budidaya. Pada awal tanam atau tahap pertumbuhan awal vegetative kondisi petakan tanam dalam keadaan macakmacak dan memasuki pertumbuhan maksimum dilakukan penggenangan. Tinggi air pada petakan disesuaikan fase pertumbuhan tanaman, setinggi $\pm 2 \mathrm{~cm}$., sedangkan sistem budidaya gogo (lahan kering) tergantung curah hujan.

c. Penyiangan

Penyiangan dilakukan secara fisik setiap 2 minggu sekali, tergantung pada keadaan gulma yang tumbuh pada lahan. Penyiangan dilakukan dengan cara mencabut gulma.

d. Pemupukan

Untuk

pertumbuhan

mengoptimalkan

pemupukan menggunakan pupuk kimia yaitu Urea, SP-36, dan $\mathrm{KCl}$ sebagai pupuk dasar dengan dosis masing-masing $200 \mathrm{~kg}$ $\mathrm{ha}^{-1}, 100 \mathrm{~kg} \mathrm{ha}{ }^{-1}$ dan $100 \mathrm{~kg} \mathrm{ha}^{-1}$. Pemberian pupuk urea, SP-36 dan $\mathrm{KCl}$ dilakukan pada umur 1 Minggu Setelah Tanam (MST) dengan cara ditugal di sekitar tanaman. Pupuk urea diberikan 2 kali yaitu setengah dosis diberikan pada umur 1 MST dan setengah dosis diberikan pada umur 8 MST.

e. Pengendalian Hama dan Penyakit

Pengendalian hama dan penyakit tanaman dilakukan secara optimal baik secara manual maupun menggunakan bahan kimia (insektisida/pestisida) sesuai dengan hama dan penyakit tanaman yang menyerang.

\section{Panen}

Panen dilakukan dengan melihat tanda-tanda minimal $85 \%$ gabah sudah menguning. Panen dilakukan dengan cara memotong batang padi yang terletak tepat di bawah pangkal daun bendera menggunakan gunting.

\section{Variabel Pengamatan}

Setiap petak diamati tiga rumpun dan setiap rumpun diamati 3 tanaman sebagai sampel. Variabel yang diamati adalah :

1. Jumlah anakan produktif, dihitung jumlah anakan yang menghasilkan malai pada tiap rumpunnya pada saat panen.

2. Panjang malai per rumpun, diukur panjang malai dari pangkal sampai ujung malai terpanjang pada tiga sampel malai per rumpun, dilakukan pada saat panen.

3. Total gabah per malai, dihitung semua gabah dari tiga sampel malai per rumpun. Perhitungan jumlah gabah per malai dilakukan setelah panen.

4. Bobot gabah isi per malai (g), dihitung dengan menimbang semua gabah kering dari 3 rumpun tanaman sampel pada kadar air $\pm 14 \%$. Perhitungan berat gabah kering dilakukan setelah panen.

5. Bobot 1000 butir gabah (g), dihitung dengan cara menimbang 1000 butir gabah kering pada kadar air $\pm 14 \%$, dilakukan setelah panen.

6. Bobot gabah kering per rumpun $(\mathrm{g})$, dihitung dengan menimbang semua gabah kering dari 3 rumpun tanaman sampel pada kadar air $\pm 14 \%$. Perhitungan berat gabah kering dilakukan setelah panen.

7. Produksi per hektar (ton), konversi dari hasil gabah kering per rumpun.

\section{Analisis data}

Data hasil pengamatan dianalisis dengan sidik ragam gabungan (Combined Anova) atau uji $\mathrm{F}$ gabungan. Apabila sidik ragam menunjukkan pengaruh signifikan $\left(\mathrm{F}_{\text {hitung }}>\mathrm{F}_{\text {tabel }}\right)$ maka dilanjutkan dengan Uji Tukey atau Honestly Significance Difference (Beda Nyata Jujur = BNJ) pada taraf kepercayaan $95 \%$. Untuk menge-tahui 
hubungan korelasi antara hasil gabah dengan komponen-komponen hasil beberapa kultivar padi ladang (Oryza sativa L.) lokal Sulawesi Tenggara yang dibudidayakan dengan sistem budidaya gogo dan budidaya sawah dilakukan analisis korelasi sederhana, menggunakan program statistika SAS 9.2.

\section{HASIL DAN PEMBAHASAN}

Hasil analisis korelasi pengaruh berbagai komponen-komponen hasil ter-hadap hasil beberapa kultivar padi ladang (Oryza sativa L.) lokal Sulawesi Tenggara yang dibudidayakan dengan sistem budidaya gogo dan sistem budidaya sawah disajikan pada Tabel 3.

Tabel 3. Korelasi antara hasil dan komponen-komponen hasil padi ladang lokal Sulawesi Tenggara

\begin{tabular}{llllllll}
\hline Variable & JAP & PM & TG & BGI & B1000 & BGR & PROD \\
\hline JAP & 1,00 & & & & & & \\
PM & $-0,44$ & 1,00 & & & & & \\
TG & $-0,23$ & $0,46^{*}$ & 1,00 & & & & \\
BGI & $-0,28$ & $0,55^{*}$ & $0,92^{*}$ & 1,00 & & & \\
B1000 & 0,04 & 0,06 & $-0,62^{*}$ & $-0,42$ & 1,00 & & \\
BGR & 0,19 & 0,36 & $0,83^{*}$ & $0,84^{*}$ & $-0,38$ & 1,00 & \\
PROD & $-0,17$ & $0,46^{*}$ & $0,59^{*}$ & $0,55^{*}$ & $-0,29$ & $0,57^{*}$ & 1,00 \\
\hline
\end{tabular}

Keterangan: JAP $=$ Jumlah Anakan Produkif, $\mathrm{PM}=$ Panjang Malai, $\mathrm{TG}=$ Toal Gabah per Malai, BGI=Bobot Gabah Isi, B1000=Bobot 1000 Butir, BGR=Bobot Gabah per Rumpun, PROD=Produksi, *=berkorelasi.

Tabel 2 menunjukkan bahwa korelasi antara produksi dan komponen-komponen hasil padi ladang lokal Sultra berkorelasi positif dan negatif. Secara umum, komponen jumlah anakan produktif tidak menunjukkan korelasi yang signifikan terhadap komponen panjang malai, total gabah per malai, bobot gabah isi, bobot 1000 butir, bobot gabah per rumpun dan produksi dengan nilai masing-masing -0,44; 0,$23 ;-0,28 ; 0,04 ; 0,19$ dan $-0,17$. Hal ini menggambarkan bahwa meningkatnya atau menurunya jumlah anakan produktif tidak memiliki hubungan yang erat terhadap komponen hasil.

Komponen panjang malai mempunyai korelasi positif dengan jumlah gabah total per malai dan bobot gabah isi dengan nilai masingmasing 0,46 dan 0,55 dan. Hal ini menunjukkan peningkatan panjang malai akan mendukung peningkatan total gabah per malai dan bobot gabah isi per malai. Semakin panjang malai maka semakin tinggi jumlah gabah isi dan total gabah per malai. Komponen panjang malai juga berkorelasi positif dengan produksi dengan nilai 0,46 . Hal ini sesuai dengan pernyataan Zhang et al., (2010) bahwa malai yang panjang dengan jumlah gabah per malai yang banyak dapat meningkatkan kepadatan gabah. Lebih lanjut dilaporkan, selain karakter panjang malai, bobot gabah isi dan persentase gabah isi, bobot 1000 butir juga memberikan pengaruh langsung terhadap hasil gabah (Kanbar et al., 2009; Min et al., 2011; Li et al., 2014; Solomon dan Wegary, 2016; Kartina et al., 2017; Suryanugraha et al., 2017; Sharif dan Ebadi, 2018; Asante et al. 2019; Zhao et al., 2020).

Komponen total gabah per malai mempunyai korelasi positif terhadap bobot gabah isi, bobot gabah per rumpun dan produksi gabah dengan nilai masing-masing 0,$92 ; 0,83$ dan 0,59 . Hal ini menunjukkan bahwa bobot gabah isi, bobot gabah per rumpun dan produksi gabah memiliki hubungan yang erat terhadap total gabah per malai. Semakin meningkat total gabah per malai maka akan diikuti dengan meningkatnya bobot gabah per rumpun yang pada akhirnya 
meningkatkan produksi padi. Namun, menunjukkan korelasi negatif terhadap bobot 1000 butir dengan nilai $-0,62$. Hal ini menunjukkan bahwa peningkatan total gabah per malai dapat berpengaruh terhadap ukuran gabah karena ukuran besar kecilnya gabah dapat menentukan bobot 1000 butir gabah.

Komponen bobot gabah isi berkorelasi positif terhadap bobot gabah per rumpun dan produksi dengan nilai 0,84 dan 0,55 . Hal ini menunjukan bahwa bobot gabah isi memilik hubungan yang erat dengan bobot gabah per rumpun dan produksi. Hal ini berarti peningkatan bobot gabah isi yang tinggi mengakibatkan komponen gabah per rumpun maupun produksi mengalami peningkatan.

Komponen bobot 1000 butir gabah menunjukkan korelasi negatif terhadap total gabah per malai dengan nilai $-0,62$. Hal ini menunjukkan bahwa total gabah per malai memiliki hubungan yang erat terhadap bobot 1000 butir. Namun, total gabah yang meningkat dan padat dapat berpengaruh negatif terhadap bobot 1000 butir karena berpengaruh pada ukuran gabah pada setiap malai. Menurut Saragih \& Wirnas (2019) bahwa bobot 1000 butir sangat dipengaruhi oleh ukuran dan bentuk gabah. Semakin besar ukuran gabah maka bobot gabah yang dihasilkan akan semakin besar, dan sebaliknya, ukuran gabah yang kecil akan menghasilkan bobot gabah yang ringan. Lebih lanjut dilaporkan bahwa semakin berat gabah dan bobot 1000 butir akan memberikan korelasi yang signifikan terhadap hasil tanaman (Kanbar et al., 2009; Hasan et al., 2011; Sugár et al., 2016; Li et al., 2019).

Komponen produksi dan komponenkomponen hasil padi ladang lokal Sulawesi Tenggara berkorelasi positif terhadap panjang malai, total gabah per malai, bobot gabah isi dan bobot gabah per rumpun dengan nilai korelasi secara berurut yaitu 0,$46 ; 0,59 ; 0,55$ dan 0,57. Berbeda dengan komponen jumlah anakan produktif dan bobot 1000 butir yang menunjukkan korelasi negatif yaitu -0,17 dan 0,29 . Berdasarkan hasil yang diperoleh, menunjukkan bahwa produksi memiliki hubungan yang erat dan berkorelasi positif dengan komponen panjang malai, total gabah per malai, bobot gabah isi dan bobot gabah per rumpun.

Peningkatan produksi padi ladang dapat dipengaruhi oleh meningkatnya total gabah per malai, bobot gabah isi dan bobot gabah per rumpun. Sebaliknya, komponen jumlah anakan produkif dan bobot 1000 butir berbanding terbalik terhadap produksi, ditunjukkan dengan korelasi negatif. Selain itu, menurunnya jumlah anakan produktif dan bobot 1000 butir dapat menurunkan produksi padi gogo lokal Sulawesi Tenggara. Yuniarti (2013), melaporkan komponen panjang malai dan gabah isi juga dapat menentukan produksi. Lebih lanjut dilaporkan bahwa, karakter lain yang dapat digunakan untuk mempengaruhi komponen hasil tanaman yaitu tinggi tanaman, jumlah anakan produktif, indeks panen, umur berbunga (Hairmansis et al., 2010; Lakshmi et al., 2014; Ahmed et al., 2016; Sadimantara et al., 2018).

Berdasarkan penjelasan di atas, maka dapat dikatan bahwa panjang malai, total gabah per malai, bobot gabah isi dan bobot gabah per rumpun merupakan komponenkomponen yang memiliki korelasi positif dan berhubungan erat dengan hasil produksi padi ladang lokal Sulawesi Tenggara. Hal ini menunjukkan bahwa ke empat komponen tersebut dapat digunakan sebagai kriteria untuk peningkatan hasil padi ladang baik di lahan sawah maupun lahan kering.

\section{KESIMPULAN}

Berdasarkan hasil dan pembahasan, dapat disimpulkan bahwa panjang malai, total gabah per malai, bobot gabah isi dan bobot gabah per rumpun merupakan kriteria yang dapat digunakan untuk mengetahui peningkatan produksi baik padi ladang yang 
dibudidayakan dengan sistem budidaya gogo maupun sistem budidaya sawah. Empat komponen tersebut memiliki korelasi positif terhadap hasil produksi padi ladang lokal Sulawesi Tenggara.

\section{UCAPAN TERIMAKASIH}

Ucapan terimakasih disampaikan kepada Kementerian Riset Teknologi dan Pendidikan Tinggi, yang telah mendanai penelitian ini melalui program PPT_BOPTN Universitas Halu Oleo tahun anggaran 2017.

\section{DAFTAR PUSTAKA}

Afa, L.O. dan A. A. Anas. 2017. Produksi Beberapa Kultivar Padi Gogo (Oryza sativa L.) Lokal Sulawesi Tenggara pada Dua Sistem Budidaya. Laporan hasil penelitian produk terapan Universitas Halu Oleo, p 75.

Ahmed, B.E.A.M., F.E. Ahmed and H.I. Dessougi. 2016. Assessments of the relationship between effective leaf area, yield componentsand protein content in wheat (Triticum aestivum L.) under water stress conditions at Eastern Sudan. Sch J Agric Vet Sci., 3(2): 155-159.

Asante, M.D., K.L. Adjah \& E. Annan-Afful. 2019. Assessment of genetic diversity for grain yield and yield component traits in some genotypes of rice (Oryza Sativa L.). Journal of Crop Science and Biotechnology, 22(2): 123-130.

Bogale, A. and K. Tesfaye. 2016. Relationship between grain yield and yield components of the Ethiopian Durum wheat genotypes at various growth stages. Tropical and Subtropical Agroecosystems, 19(1): 81-91.

Habib, S.H., M.K. Bashar, M. K. Zaman, M.S. Ahmed, and E.S.M.H. Rashid. 2005. Genetic analysis and morphophysiological selection criteria for traditional biroin Bangladesh rice germplasm. J. Biol. Sci. 5(3):315-318.

Hairmansis A., B. Kustianto, Supartopo, and Suwarno. 2010. Correlation analysis of agronomic characters and grain yield of rice for tidal swamp areas. Indonesian Journal of Agricultural Science 11(1): 11-15.

Hasan, M.J., M.U. Kulsum, A. Akter, A.S.M. Masuduzzaman and M.S. Ramesha. 2011. Genetic variability and character association for agronomic traits in hybrid rice (Oryza Sativa L.). Bangladesh J. Pl. Breed. Genet, 24(1): 45-51.

Kanbar, A., M. Toorchi and H.E. Shashidhar. 2009. Relationship between root and yield morphological characters in rainfed low land rice (Oryza sativa L.). Cereal Research Communications, 37(2): 261-268.

Kartina, N., B.P. Wibowo, I.A. Rumanti dan Satoto. 2017. Korelasi hasil gabah dan komponen hasil padi hibrida. Penelitian Pertanian Tanaman Pangan, 1(1): 11-19.

Lakshmi, M.V., Y. Suneetha, G. Yugandhar and N.V. Lakshmi. 2014. Correlation studies in rice (Oryza sativa L.). International Journal of Genetic Engineering and Biotechnology, 5(2): 121-126.

Li, G., J. Zhang, C. Yang, Y. Song, C. Zheng, S. Wang, Z. Liu and Y. Ding. 2014. Optimal yield-related attributes of irrigated rice for high yield potential based on path analysis and stability analysis. The Crop Journal, 2(4): 235243.

Li, R., M. Li, U. Ashraf, S. Liu and J. Zhang. 2019. Exploring the relationships between yield and yield-related traits for rice varieties released in China From 1978 to 2017. Front. Plant Sci. 10:543.

Limbongan, Y.L. 2008. Analisis genetik dan seleksi genotipe unggul padi sawah (Oryza sativa L.) untuk adaptasi pada ekosistem dataran tinggi. Disertasi. Sekolah Pasca-sarjana, IPB, p147.

Min, H., Z. Ying-bin, J.Peng, X. Bing, M. Ibrahim, A.O. He-jun. 2011. Relationship between grain yield and 
yield components in super hybrid rice. Agricultural Sciences in China, 10(10):1537-1544.

Perween, S., A. Kumar, F. Adan, J. Kumar, P. Raj and A. Kumar. 2020. Correlation and path analysis of yield components in rice (Oryza sativa L.) under irrigated and reproductive stage drought stress condition. British Journal of Applied Science \& Technology, 39(8): 60-68.

Rachmawati, R.Y., Kuswanto, dan S.L. Purnamaningsih. 2014. Uji keseragaman dan analisis sidik lintas antara karakter agronomis dengan hasil pada tujuh genotipe padi hibrida japonica. Jurnal Produksi Tanaman, 2(4):292-300.

Sadimantara, G.R., W. Nuraida, N.W.S Suliartini and Muhidin. 2018. Evaluation of some new plant type of upland rice (Oryza sativa L.) lines derived from cross breeding for the growth and yield characteristics. IOP Conf. Series: Earth and Environmental Science, 157: 1-6.

Saragih, R.I.K dan D. Wirnas. 2019. Varian among F4 Lives generation from Crossing on IPB $4 \mathrm{~S}$ and Situ Patenggang. Bul Agrohorti, 7(1) : 3846.

Sharifi P. and A.A. Ebadi. 2018. Relationships of rice yield and quality based on genotype by trait (GT) biplot. An. Acad. Bras. Ciênc, 90 (1):343-356.

Solomon, H. and D. Wegary. 2016. Phenotypic correlation and path coefficient analysis of yield and yield component in rice (Oryza Sativa). Int $J$ Res Rev. 3(7): 1-5.
Sugár, E., Z. Berzsenyi, T. Árendásand and P. Bónis. 2016. Effect of nitrogen fertilization and genotype on the yield and yield components of winter wheat. Die Bodenkultur: Journal of Land Management, Food and Environment, 67(1):25-34.

Suryanugraha W.A., Supriyanta dan Kristamtini. 2017. Keragaan sepuluh kultivar padi lokal (Oryza sativa L.) Daerah Istimewa Yogyakarta. Vegetalika, 6(4): 55-70.

Wirnas, D., I. Widodo, Sobir, Trikoesoemaningtyas dan D. Sopandie, 2007. Pemilihan karakter agronomi untuk menyusun indeks seleksi pada 11 populasi kedelai generasi F6. J. Agron. Indonesia 34(1):19-24.

Yoshida, S. 1981. Fundamentals of Rice Crop Science. International Rice Research Institut. Manila.

Yuniarti S. dan S. Kurniawati, 2013. Keragaman Komponen Pertumbuhan dan Hasil Varietas Unggul Baru Padi pada Lahan Rawan banjir di Kabupaten Pandeglang, Banten. Buletin IKATAN 3: 2.

Zhang H., G.L. Tan, Y.G. Xue, L.J. Liu dan J.C. Yang, 2010. Changes in grain yield and morphological an Physiological charcteristic during 60 year evolution of Japonica rice cultivars in Jiangsu. Acta Agron Sin 36:133-140.

Zhao, H., Z. Mo, Q. Lin, S. Pan, M. Duan, H. Tian, S. Wang and X. Tang. 2020. Relationships between grain yield and agronomic traits of rice in Southern China. Chil. j. agric. Res, 80(1): 7279. 